\title{
A SOLUTION TO THE CRYSTAL STRUCTURES OF BISMUTITE AND BEYERITE
}

\author{
JOEL D. GRICE ${ }^{\S}$ \\ Canadian Museum of Nature, P.O. Box 3443, Station D, Ottawa, Ontario K1P 6P4, Canada
}

\begin{abstract}
The crystal structures of bismutite, $\mathrm{Bi}_{2}\left(\mathrm{CO}_{3}\right) \mathrm{O}_{2}, a 3.865(2), b 3.862(2), c$ 13.675(6) $\AA, V$ 204.1(2) $\AA^{3}$, space group Imm2, $Z=2$, and beyerite, $\mathrm{CaBi}_{2}\left(\mathrm{CO}_{3}\right)_{2} \mathrm{O}_{2}, a 3.7729(5), b 3.7742(7), c$ 21.726(4) $\AA$, $V 309.4(1) \AA^{3}$, space group Immm, $Z=2$, have been refined to $R$ indices of 0.0206 and 0.0145 on the basis of 184 and 258 unique reflections. Although the cell and the distribution of diffraction intensities obey tetragonal symmetry, for both these minerals, attempts to solve the structure with tetragonal symmetry led to stereochemical problems. Introduction of a twin plane via reflection on $\{110\}$ for orthorhombic symmetry simulates tetragonal diffraction-intensity distribution for the peudo-merohedral twin, and gives a structure with sensible stereochemistry. All large cations, $\mathrm{Ca}$ and $\mathrm{Bi}$, have [8]-coordination, and $\mathrm{Bi}^{3+}$ shows stereoactive lone-pair behavior. The structures are layered with $\mathrm{Bi}-\mathrm{O}$ layers, a $\mathrm{Ca}-\mathrm{O}$ layer in beyerite and $\left(\mathrm{CO}_{3}\right)$ layers with the plane of the $\left(\mathrm{CO}_{3}\right)$ group orthogonal to the plane of the layer. Bismutite and beyerite have crystal structures typical of "Sillén" phases, and they are closely related structurally to the only other Bi oxycarbonate mineral, kettnerite.
\end{abstract}

Keywords: bismutite, beyerite, crystal structure, pseudo-merohedral twin, stereoactive lone-pair of electrons, oxycarbonate.

\section{SOMMAIRE}

La structure cristalline de la bismutite, $\mathrm{Bi}_{2}\left(\mathrm{CO}_{3}\right) \mathrm{O}_{2}, a$ 3.865(2), $b$ 3.862(2), c 13.675(6) $\AA, V$ 204.1(2) $\AA^{3}$, groupe spatial Imm $2, Z=2$, et celle de la béyerite, $\mathrm{CaBi}_{2}\left(\mathrm{CO}_{3}\right)_{2} \mathrm{O}_{2}, a 3.7729(5), b 3.7742(7), c$ 21.726(4) $\AA$, V309.4(1) $\AA^{3}$, groupe spatial Immm, $Z=2$, ont été affinées jusqu'à un résidu $R$ de 0.0206 et 0.0145 sur la base de 184 et 258 réflexions uniques. Quoique la maille et la distribution des intensités de diffraction répondent à une symétrie tétragonale dans les deux cas, toute tentative de solution avec une telle symétrie mène à des incompatibilités stéréochimiques. L'introduction d'un plan de macle par réflexion sur $\{110\}$ dans un symétrie orthorhombique simule une symétrie tétragonale dans la distribution des intensités de diffraction dans le cas d'une macle par pseudo-méroédrie, et produit une structure avec une stéréochimie raisonnable. Les cations de taille importante, Ca et $\mathrm{Bi}$, possèdent une coordinence [8], et le $\mathrm{Bi}^{3+}$ montre un comportement attribuable à la présence d'une paire d'électrons isolée stéréoactive. Il s'agit de structures en couches, avec des niveaux $\mathrm{Bi}-\mathrm{O}, \mathrm{Ca}-\mathrm{O}$ (dans la béyerite) et $\left(\mathrm{CO}_{3}\right)$, l'orientation des groupes $\left(\mathrm{CO}_{3}\right)$ étant orthogonale par rapport au plan des couches. Du point de vue structural, la bismutite et la béyerite sont typiques des phases dites de "Sillén", et elles ressemblent à la seule phase minérale oxycarbonatée de bismuth, la kettnerite.

(Traduit par la Rédaction)

Mots-clés: bismutite, béyerite, structure cristalline, macle par pseudo-méroédrie, paire isolée d'électrons stéréoactive, oxycarbonate.

\section{INTRODUCTION}

With the successful solution of the crystal structure of kettnerite (Grice et al. 1999), it was encouraging to pursue a crystal-structure determination of the other bismuth oxycarbonates beyerite, $\mathrm{CaBi}_{2}\left(\mathrm{CO}_{3}\right)_{2} \mathrm{O}_{2}$, and bismutite, $\mathrm{Bi}_{2}\left(\mathrm{CO}_{3}\right) \mathrm{O}_{2}$. As in the case of kettnerite, both minerals are reported in the literature as being tetragonal, but this determination leaves no clear resolution to the crystal-structure problem of an impossible and nonresolvable configuration for the carbonate group polyhedra. An earlier determination of the structure on synthetic material by Lagergrantz \& Sillén (1948) placed both bismutite and beyerite in tetragonal spacegroup $14 / \mathrm{mmm}$. Although these authors were able to determine the general location of the large cations and the oxygen atoms not part of the carbonate groups, they could not define the placement of the $\left(\mathrm{CO}_{3}\right)$ groups themselves. The problems are two-fold: they had to (1) avoid 4-fold crystallographic sites, which give the carbonate group an unacceptable tetragonal pyramid form, and (2) find sufficient space for the entire group within these compact cells. Their deductions and calculations led them to "think it more probable that every $\mathrm{CO}_{3}$ group

§ E-mail address: jgrice@mus-nature.ca 
can rotate in two mutually perpendicular orientations: parallel to (110) or parallel to (110), and that clusters of a variable number of "cogging" $\mathrm{CO}_{3}$ groups are continuously being formed and dissolved." The authors did not consider trying a lower-symmetry space group. A flaw in their deductions was the orientation of the $\left(\mathrm{CO}_{3}\right)$ groups. They calculated that the (100) orientation would not provide sufficient space for the groups, but in fact it does, as will be seen in this paper.

\section{EXPERIMENTAL}

The experimental method used for collection of intensity data for bismutite and beyerite was the same as used by Grice et al. (1999) for kettnerite. For the intensity-data measurements, a thin $\{001\}$ cleavage plate of bismutite (Canadian Museum of Nature sample number CMNMC 56898) measuring $0.10 \times 0.10 \times 0.02 \mathrm{~mm}$ and another of beyerite (Smithsonian Institution sample number C2251) measuring $0.12 \times 0.12 \times 0.04 \mathrm{~mm}$ were used. Intensity data were collected on a Siemens $P 4$ four-circle diffractometer operated at $50 \mathrm{kV}, 40 \mathrm{~mA}$, with graphite-monochromatized $\mathrm{MoK} \alpha$ radiation. The setting angles of 17 reflections (bismutite) and 31 reflections (beyerite) were used to determine the orientation matrix and refine the cell dimensions. A complete sphere of diffraction data $( \pm h \pm k \pm l)$ was collected up to $2 \theta=60^{\circ}$ using a $\theta: 2 \theta$ scan-mode, with scan speeds inversely proportional to intensity, varying from 1.5 to $29.3 \%$ minute. All calculations were done with the SHELXTL PC PLUS system of programs. For the plateabsorption correction, 14 intense diffraction-maxima in the range 8 to $57^{\circ} 2 \theta$ were chosen for $\Psi$ diffractionvector scans at $5^{\circ}$ intervals of $\Psi$ (North et al. 1968). With reflections omitted within a $7^{\circ}$ (bismutite) and $15^{\circ}$ (beyerite) glancing angle of the plate, the converging $R$ refinement for the $\Psi$-scan data set (980 reflections) decreased from $13.8 \%$ before correction to $2.9 \%$ for bismutite and from $18.1 \%$ to $2.9 \%$ for beyerite after the absorption correction. Information relevant to the data collections is given in Table 1.

TABLE 1. DATA COLLECTION AND STRUCTURE-REFINEMENT DATA, BISMUTITE AND BEYERITE

\begin{tabular}{|c|c|c|}
\hline & Bismutite & Beyerite \\
\hline Simplified formula & $\mathrm{Bi}_{2}\left(\mathrm{CO}_{3}\right) \mathrm{O}_{2}$ & $\mathrm{CaBi}_{2}\left(\mathrm{CO}_{3}\right)_{2} \mathrm{O}_{2}$ \\
\hline Radiation / $\mu\left(\mathrm{mm}^{-1}\right)$ & $\mathrm{MoK \alpha} / 86$ & $\mathrm{MoK \alpha} / 58$ \\
\hline Space group & $\operatorname{Imm} 2(\# 44)$ & Immm (\#71) \\
\hline$a(\AA)$ & $3.865(2)$ & $3.7729(5)$ \\
\hline$b(\AA)$ & $3.862(2)$ & $3.7742(7)$ \\
\hline$c(\AA)$ & $13.675(6)$ & $21.726(4)$ \\
\hline$V\left(\AA^{3}\right) / Z$ & $204.1(2) / 2$ & $309.4(1) / 2$ \\
\hline Reflections unique/merged & $725 / 184$ & $1006 / 258$ \\
\hline$R_{1} / w R_{2} /$ Goof & $0.0206 / 0.0612 / 1.131$ & $0.0145 / 0.0409 / 0.907$ \\
\hline \multicolumn{3}{|c|}{ 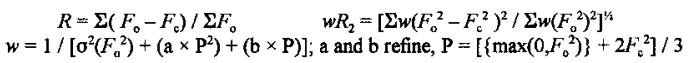 } \\
\hline
\end{tabular}

The chemical composition of each sample was determined by electron microprobe. Average results of three analyses (in wt.\%) are: bismutite, $\mathrm{Bi}_{2} \mathrm{O}_{3} 92.81$, $\mathrm{CO}_{2} 8.67$ (calculated), total 101.58; and beyerite, $\mathrm{CaO}$ 8.34, $\mathrm{PbO} 0.87, \mathrm{Bi}_{2} \mathrm{O}_{3} 75.86, \mathrm{CO}_{2} 14.11$ (calculated), total 99.18. These analytical data give empirical formulae (calculated on the basis of a fixed number of $\mathrm{O}$ atoms): bismutite, $\mathrm{Bi}_{2.00}\left(\mathrm{CO}_{3}\right) \mathrm{O}_{2}$, and beyerite, $\left(\mathrm{Ca}_{0.93}\right.$ $\left.\mathrm{Pb}_{0.02} \mathrm{Bi}_{0.02}\right)_{\Sigma 0.97} \mathrm{Bi}_{2.00}\left(\mathrm{CO}_{3}\right)_{2} \mathrm{O}_{2}$. The results indicate that both minerals are essentially ideal end-members.

\section{Structure Solution And Refinement}

From precession photographs and four-circle diffractometer data, bismutite and beyerite seem tetragonal. The crystals of bismutite are platy, clove-brown in color and with a distinctly biaxial negative optical indicatrix $\left(2 V \approx 45^{\circ}\right)$. The crystals of beyerite tend to be granular but with a platy cleavage or parting, yellow in color, with a uniaxial indicatrix that may have a negative sign or, more commonly, no discernible sign at all. The difference in the optics between these two minerals is significant when considering the possibility of twinning. The distinct $2 \mathrm{~V}$ of bismutite indicates a space group of symmetry lower than tetragonal, whereas that of beyerite could be tetragonal or a pseudomerohedral twin of a crystal system of lower symmetry. The systematic extinctions for both minerals indicate possible space-groups $I 4 / \mathrm{mmm}, \overline{4} 2 \mathrm{~m}, I 4 \mathrm{~mm}$ or $I 422$. Assuming tetragonal symmetry and assigning phases to a set of normalized structure-factors gave a mean value $\left|E^{2}-1\right|$ of 0.558 (bismutite) and 0.628 (beyerite). These anomalously low values, even below the value (0.736) statistically characteristic of noncentrosymmetric space-groups, is one possible indication of twinning (Herbst-Irmer \& Sheldrick 1998, Grice et al. 1999). As the crystal structure of these two minerals is closely related to that of kettnerite, an orthorhombic symmetry was assumed. For both minerals, the $E$-map coordinates for an $\operatorname{Imm} 2$ model were assigned the appropriate scattering curves. This particular space-group was chosen with an orientation such that the c axis of the pseudo-fourfold axis became the twofold axis, the one set of $m$ planes of the tetragonal cell perpendicular to the principal axes were retained, and the other set of $m$ planes intermediate to the principal axes in the pseudotetragonal cell were eliminated. These intermediate axes are those that generate the impossible five-fold coordination about the $\mathrm{C}$ atom. Once a reasonable structural model was determined for each mineral, it was checked with MISSYM (Le Page 1987), a program developed to check for symmetry elements not recognized in the assigned spacegroup. The space groups determined were Imm 2 for bismutite and Immm for beyerite. The change to a centrosymmetric space-group for beyerite was substantiated by the subsequent refinement of the structure.

With the correct space-groups, the models refined to $R=0.0260$ (bismutite) and $R=0.0396$ (beyerite) with 
TABLE 2. ATOMIC POSITIONS AND ANISOTROPIC DISPLACEMENT PARAMETERS $\left(U \mathbf{s} \AA^{2}\right)$

\begin{tabular}{|c|c|c|c|c|c|c|c|c|c|c|}
\hline & $x$ & $y$ & $z$ & $U_{11}$ & $U_{22}$ & $U_{33}$ & $U_{23}$ & $U_{13}$ & $U_{12}$ & $U_{\mathrm{eq}}$ \\
\hline \multicolumn{11}{|c|}{ BISMUTITE } \\
\hline $\mathrm{Bil}$ & 0 & 0 & 0 & $0.0147(7)$ & $0.0116(8)$ & $0.0228(4)$ & 0 & 0 & 0 & $0.0164(3)$ \\
\hline $\mathrm{Bi} 2$ & $1 / 2$ & $1 / 2$ & $0.18433(5)$ & $0.0150(9)$ & $0.0061(7)$ & $0.0303(5)$ & 0 & 0 & 0 & $0.0171(3)$ \\
\hline $\mathrm{C}$ & 0 & 0 & $0.338(3)$ & $0.014(5)$ & $0.014(5)$ & $0.006(4)$ & 0 & 0 & 0 & $0.012(2)$ \\
\hline 01 & 0 & $1 / 2$ & $0.104(2)$ & $0.018(6)$ & $0.019(6)$ & $0.020(6)$ & 0 & 0 & 0 & $0.019(4)$ \\
\hline $\mathrm{O} 2$ & $1 / 2$ & 0 & $0.102(2)$ & $0.016(6)$ & $0.010(5)$ & $0.018(6)$ & 0 & 0 & 0 & $0.014(3)$ \\
\hline $\mathrm{O} 3$ & 0 & $0.286(4)$ & $0.305(1)$ & $0.038(6)$ & $0.037(5)$ & $0.038(5)$ & $-.000(4)$ & 0 & 0 & $0.038(3)$ \\
\hline O4 & 0 & 0 & $0.443(1)$ & $0.031(6)$ & $0.033(6)$ & $0.018(4)$ & 0 & 0 & 0 & $0.027(3)$ \\
\hline \multicolumn{11}{|c|}{ BEYERITE } \\
\hline $\mathrm{Bi}$ & 0 & 0 & $-.30915(1)$ & $0.0111(1)$ & $0.0114(1)$ & $0.0091(1)$ & 0 & 0 & 0 & $0.01051(6)$ \\
\hline $\mathrm{Ca}$ & 0 & 0 & $1 / 2$ & $0.0111(9)$ & $0.010(1)$ & $0.0119(7)$ & 0 & 0 & 0 & $0.0109(4)$ \\
\hline $\mathrm{C}$ & $1 / 2$ & $1 / 2$ & $0.4107(3)$ & $0.012(3)$ & $0.026(4)$ & $0.004(2)$ & 0 & 0 & 0 & $0.014(1)$ \\
\hline 01 & $1 / 2$ & 0 & $0.2558(3)$ & $0.006(2)$ & $0.007(2)$ & $0.000(2)$ & 0 & 0 & 0 & $0.005(1)$ \\
\hline $\mathrm{O} 2$ & $1 / 2$ & $0.207(1)$ & $0.4379(2)$ & $0.014(2)$ & $0.015(2)$ & $0.018(2)$ & $0.007(2)$ & 0 & 0 & $0.0158(9)$ \\
\hline $\mathrm{O} 3$ & $1 / 2$ & $1 / 2$ & $0.3498(2)$ & $0.031(3)$ & $0.024(3)$ & $0.004(2)$ & 0 & 0 & 0 & $0.020(1)$ \\
\hline
\end{tabular}

anisotropic-displacement parameters. Employing a twin law with a mirror plane parallel to (110), the crystal structures refined to $R=0.0206$ (bismutite) and $R=$ 0.0145 (beyerite). With twinned crystals, one must be careful to apply appropriate constraints, or else the refinement becomes unstable (Hönle \& von Schnering 1988). The contribution of one twin component refined to 0.41 (1) for bismutite and 0.50(1) for beyerite. For the bismutite crystal, the distinct biaxial character of the optical properties and the marginal improvement of the structure refinement with the twin law applied indicate that this crystal is not twinned or at least not twinned to a significant degree. In contrast, the crystal of beyerite displayed an irregular uniaxial figure, and the refinement as a twin led to a significant improvement. This improvement in the crystal-structure model can only be the result of fine-scale pseudomerohedral twinning. The final residual electron-densities are +3.30 and $-1.32 e^{-/}$ $\AA^{3}$ and +0.95 and $-1.00 \AA^{3}$ for bismutite and beyerite, respectively. Table 2 lists the final positional and anisotropic-displacement parameters, Table 3 gives the selected interatomic distances. Observed and calculated
TABLE 3. SELECTED BOND-DISTANCES $(\AA)$ AND ANGLES $\left({ }^{\circ}\right)$, BISMUTITE AND BEYERITE

\begin{tabular}{|c|c|c|c|}
\hline \multicolumn{4}{|c|}{ Bismutite } \\
\hline Bil-O1 & $2.40(1) \times 2$ & $\mathrm{Bi} 2-\mathrm{O} 1$ & $2.22(1) \times 2$ \\
\hline $\mathrm{Bi} 1-\mathrm{O} 2$ & $2.39(2) \times 2$ & $\mathrm{Bi2}-\mathrm{O} 2$ & $2.23(1) \times 2$ \\
\hline Bil-O4 & $2.842(4) \times 4$ & $\mathrm{Bi} 2-\mathrm{O} 3$ & $2.67(1) \times 4$ \\
\hline $\mathrm{C} \sim \mathrm{O} 3$ & $1.20(2) \times 2$ & $\mathrm{O} 3-\mathrm{C}-\mathrm{O} 3$ & $134(4)$ \\
\hline $\mathrm{C}-\mathrm{O} 4$ & $1.42(4)$ & $\mathrm{O} 3-\mathrm{C}-\mathrm{O} 4$ & $113(2)$ \\
\hline \multicolumn{4}{|c|}{ Beyerite } \\
\hline $\mathrm{Bi}-01$ & $2.214(3) \times 2$ & $\mathrm{Ca}-\mathrm{O} 2$ & $2.447(3) \times 8$ \\
\hline $\mathrm{Bi}-\mathrm{Ola}$ & $2.356(4) \times 2$ & & \\
\hline $\mathrm{Bi}-\mathrm{O} 3$ & $2.809(2) \times 4$ & & \\
\hline $\mathrm{C}-\mathrm{O} 2$ & $1.253(5) \times 2$ & $\mathrm{O} 2-\mathrm{C}-\mathrm{O} 2$ & $123.8(7)$ \\
\hline $\mathrm{C}-\mathrm{O} 3$ & $1.325(8)$ & $\mathrm{O} 2-\mathrm{C}-\mathrm{O} 3$ & $118.1(3) \times 2$ \\
\hline
\end{tabular}

structure-factors have been submitted to the Depository of Unpublished Data, CISTI, National Research Council of Canada, Ottawa, Ontario K1A 0S2, Canada. (a)

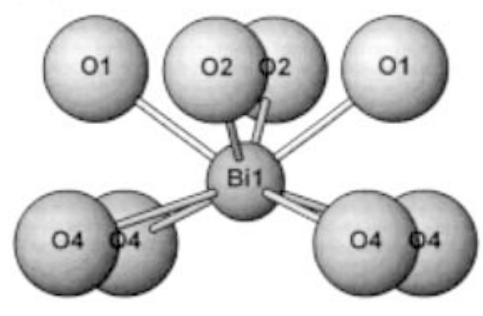

(b)

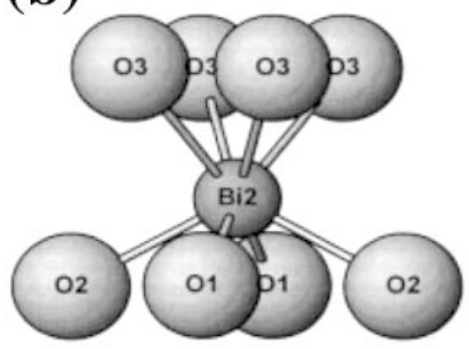

(c)

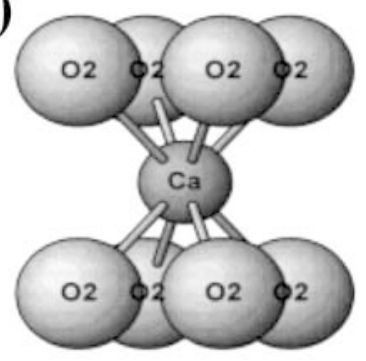

FIG. 1. The large-cation coordinations in oblique projection with [001] vertical: (a) Bi1 in bismutite, (b) Bi2 in bismutite, and (c) $\mathrm{Ca}$ in beyerite. 
(a)

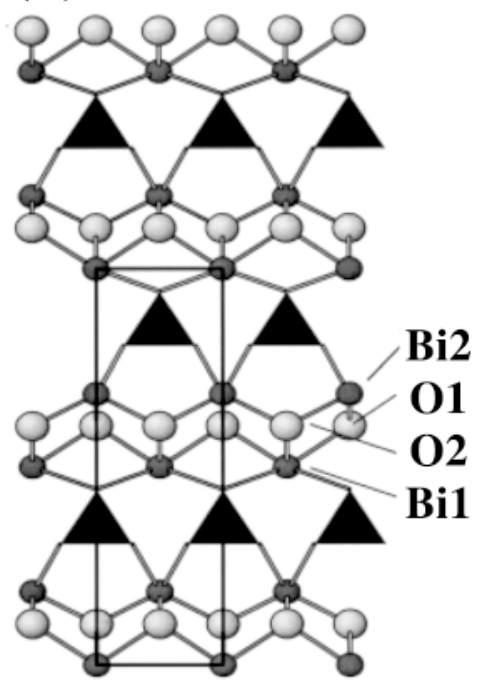

(b)

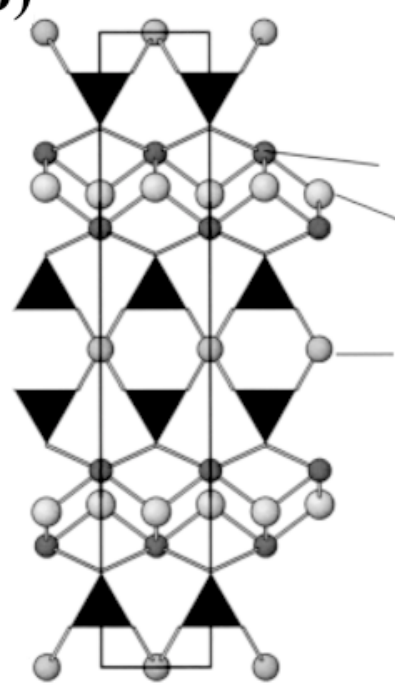

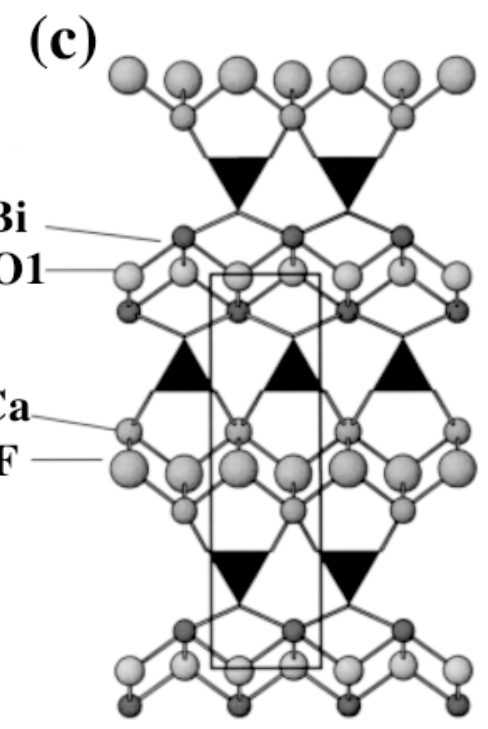

FIG. 2. The layered structures of (a) bismutite, (b) beyerite and (c) kettnerite projected on (100) with the c axis vertical. The $\left(\mathrm{CO}_{3}\right)$ polyhedra are filled triangles. The unit cell is outlined.

\section{Description of the Crystal Structures}

Bismutite has two large-cation sites with similar but distinct polyhedra. The Bil polyhedron, with [8]-coordination, is a square antiprism compressed along [001] (Fig. 1a). The $\mathrm{O} 1$ and $\mathrm{O} 2$ atoms occur at the center of the cube edges with short $\mathrm{Bi}-\mathrm{O}$ bond-lengths, $2.40 \AA$, whereas the $\mathrm{O} 4$ atoms occur at the corners of the cube, giving long bond-lengths, $2.842 \AA$. The compression along [001] is a consequence of the stereoactive lonepair of electrons associated with $\mathrm{Bi}^{3+}$ ions. The stereochemically active lone-pair of electrons also manifests itself in the unequal bond-lengths with a considerable increase in the $\mathrm{Bi}-\mathrm{O} 4$ bond length relative to that of $\mathrm{Bi}-\mathrm{O} 1$ and $\mathrm{Bi}-\mathrm{O} 2$. The $\mathrm{Bi} 2$ polyhedron also has [8]coordination, but the square antiprism is skewed to a truncated tetrasphenoid (Fig. 1b). In this unusual configuration, the bond lengths are shorter, with $\mathrm{Bi} 2-\mathrm{O} 1$ and $\mathrm{Bi} 2-\mathrm{O} 2$ at 2.23 and $\mathrm{Bi} 2-\mathrm{O} 3$ at $2.67 \AA$. Also, the compression along [001] is much less important, and one can conclude that the stereoactive lone-pair of electrons associated with $\mathrm{Bi}^{3+}$ ions is not as evident as in the Bi1 polyhedron because these electrons are more involved in bonding, thus shortening the bond lengths.

Beyerite also has two large-cation sites with similar but distinct polyhedra. The Bi polyhedron is a square antiprism like the Bil polyhedron of bismutite, having the $\mathrm{O} 1$ atom at the center of the cube edges with short Bi-O1 bond-lengths, 2.214 and $2.365 \AA$, whereas the $\mathrm{O} 3$ atoms occur at the corners of the cube, giving long bondlengths of $2.809 \AA$ . The Ca polyhedron also has [8]-coor- dination, and it defines a rhombic prism with the $\mathrm{O} 2$ atoms at the corners of the prism at a $\mathrm{Ca}-\mathrm{O} 2$ distance of $2.447 \AA$ (Fig. 1c). The distinct nature of these two polyhedra, combined with the stereoactive lone-pair behavior of $\mathrm{Bi}^{3+}$, lead to complete order of the $\mathrm{Bi}$ and $\mathrm{Ca}$ atoms.

Typical of carbonate structures, bismutite and beyerite are layered (Fig. 2), with Bi-O layers in both bismutite and beyerite, and an additional $\mathrm{Ca}-\mathrm{O}$ layer in beyerite. Both structures have a segregated "standingon-end" (Grice et al. 1994) carbonate layer. The "standing-on-end" layered arrangement of the bismuth oxycarbonates resembles that found in the rare-earth element $(R E E)$ fluorocarbonate minerals, such as bastnäsite-(Ce) (Ni et al. 1993) and the REE bicarbonate thomasclarkite-(Y) (Grice \& Gault 1998). This type of layering is characteristic of carbonates with cations of high coordination-number and a high ratio of cations relative to carbonate groups. In bismutite, all $\left(\mathrm{CO}_{3}\right)$ polyhedra have their apex pointing in the same direction along the $\mathbf{c}$ axis, resulting in a polar, noncentrosymmetric space-group, whereas in the centrosymmetric structure of beyerite, the $\left(\mathrm{CO}_{3}\right)$ polyhedra point in either direction along the $\mathbf{c}$ axis. The kettnerite structure (Grice et al. 1999 ) (Fig. 2c) might be considered a hybrid of the bismutite and beyerite structures. The $\mathrm{Ca}-\mathrm{O}$ layer of beyerite is replaced by a $\mathrm{Ca}-\mathrm{O}-\mathrm{F}$ in kettnerite. The Ca-O-F polyhedron in kettnerite is a truncated tetrasphenoid differing significantly from the $\mathrm{Ca}-\mathrm{O}$ square antiprism of beyerite.

As would be expected, the general features of the three oxycarbonates, bismutite, beyerite and kettnerite 
(a)

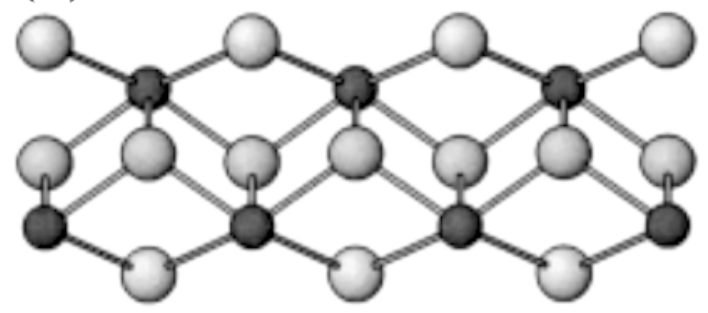

(b)

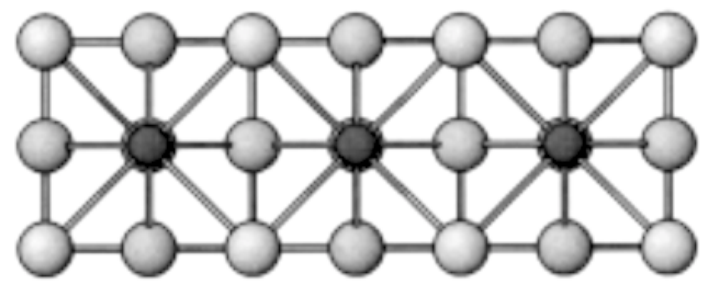

FIG. 3. The Bi-O layer in beyerite and kettnerite projected on (a) (100) and (b) (001). The $\mathrm{Bi}^{3+}$ atom is a small, dark filled circle, and the $\mathrm{O}^{2-}$ atom is larger and has lighter shading.

\section{(a)}

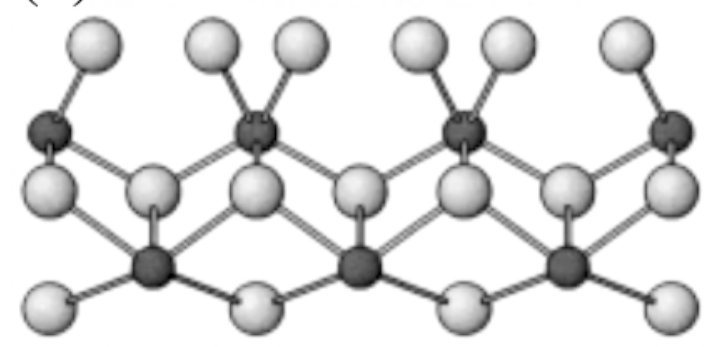

(b)

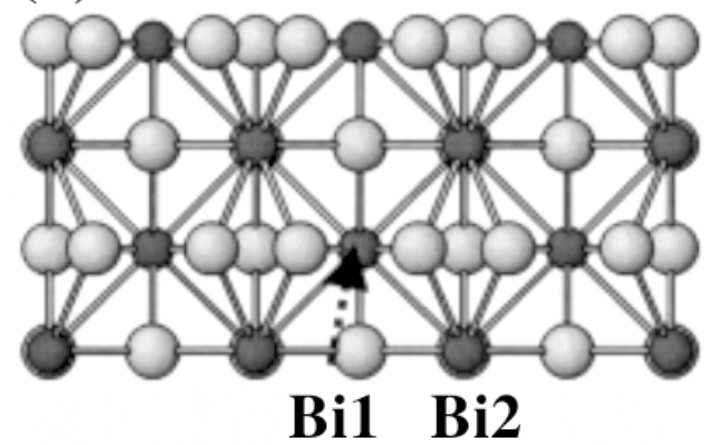

FIG. 4. The Bi-O layer in bismutite projected on (a) (100) and (b) (001). The $\mathrm{Bi}^{3+}$ atom is a small, dark filled circle, and the $\mathrm{O}^{2-}$ atom is larger and has lighter shading. are the same. All three can be considered as "Sillén phases" (Sillén 1942), which initially were considered a series of bismuth oxyhalides, but later shown to include a wider group of chemical compounds including $\mathrm{Pb}, \mathrm{W}$ and $\mathrm{Sb}$ oxyhalides and the carbonate, kettnerite (Grice \& Dunn 2000). Sillén phases are typically tetragonal or pseudotetragonal, with $a \approx b \approx 4$ or $4 \sqrt{ } 2$ (the diagonal) $\AA$ and $c \approx n \times 7 \AA$. This is certainly true for the three bismuth oxycarbonates mentioned here, as in the original descriptions, all three minerals were characterized as tetragonal with $a \approx 3.8 \AA$. This distance is the oxygen-oxygen separation at the corners of the square antiprism. The $7 \AA c$-repeat is also evident: kettnerite $c=13.57 \AA(\approx 2 \times 7 \AA)$; beyerite, $\mathrm{CaBi}_{2}\left(\mathrm{CO}_{3}\right)_{2} \mathrm{O}_{2}, c=21.76 \AA(\approx 3 \times 7 \AA)$; bismutite, $\mathrm{Bi}_{2}\left(\mathrm{CO}_{3}\right) \mathrm{O}_{2}, c=13.70 \AA(\approx 2 \times 7 \AA)$. Differences among the three $\mathrm{Bi}$ oxycarbonate structures arise from subtle but significant variations in combinations of the polyhedra hosting the large cation, all of which have 8fold coordination. The fundamental layer is composed of large cations, all of which have square antiprism polyhedra, as in the $\mathrm{Bi}-\mathrm{O}$ layers of beyerite and kettnerite (Fig. 3). In bismutite, there is a change in the Bi-O layer brought about by the differing polyhedra of the two $\mathrm{Bi}$ atoms i.e., the $\mathrm{Bi1}-\mathrm{O}$ square antiprism versus the truncated tetrasphenoid of $\mathrm{Bi} 2-\mathrm{O}$ polyhedron (Fig. 4). This layer differs from the $\mathrm{Ca}-\mathrm{O}-\mathrm{F}$ layer in kettnerite, which consists of two units of truncated tetrasphenoids (Fig. 5). The $\mathrm{Ca}-\mathrm{O}$ layer of beyerite consists of a set of rhombic prism polyhedra (Fig. 6). In Figures 3, 4, 5 and 6, one can see that the degree of cation-anion packing varies in each layer, with both $\mathrm{Bi}$ and $\mathrm{Ca}$ being able to assume two different polyhedra.

Carbonate minerals usually contain alkali, alkalineearth and rare-earth elements as cations. As all of these elements have either a low valence or a large coordination number, they are weak Lewis acids. Weak Lewis acids bond with weak Lewis bases, and thus there are favorable crystal-chemical conditions for the presence of $(\mathrm{OH})^{-}$and $\left(\mathrm{H}_{2} \mathrm{O}\right)$ groups in carbonate minerals, which explains why oxycarbonates are a rarity in minerals. The accommodation of non-carbonate oxygen atoms in minerals is made possible by the unusual electronic properties of the elements $\mathrm{Bi}, \mathrm{Pb}, \mathrm{Te}$ and $\mathrm{U}$ (Grice et al. 1999). For example, the set of four short bond-lengths associated with $\mathrm{Bi}^{3+}$ and its stereoactive lone-pair behavior satisfies the higher bond-valence requirements of oxygen relative to the more common carbonate minerals containing weak Lewis bases with $(\mathrm{OH})^{-}$and $\left(\mathrm{H}_{2} \mathrm{O}\right)$ groups. Thus the minerals beyerite $\mathrm{CaBi}_{2}\left(\mathrm{CO}_{3}\right)_{2} \mathrm{O}_{2}$, bismutite $\mathrm{Bi}_{2}\left(\mathrm{CO}_{3}\right) \mathrm{O}_{2}$ and kettnerite $\mathrm{CaBi}\left(\mathrm{CO}_{3}\right) \mathrm{OF}$ can crystallize and remain stable in highly oxidizing environments.

\section{ACKNOWLEDGEMENTS}

I dedicate this paper to Louis Cabri, a friend and colleague for over 25 years. Louis was instrumental in getting me my first job as a research mineralogist, and 
(a)

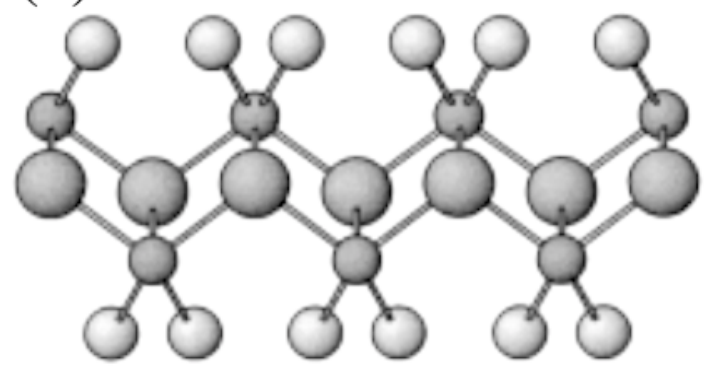

(b)

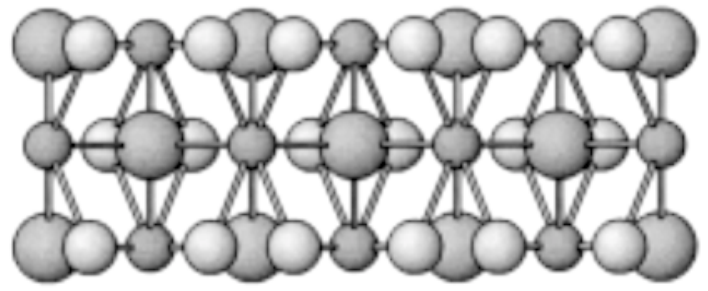

FIG. 5. The Ca-O-F layer in kettnerite projected on (a) (100) and (b) (001). The $\mathrm{Ca}^{2+}$ atom is the smallest circle, $\mathrm{O}^{2-}$ is next in size, and $\mathrm{F}^{-}$is the largest.

has been a mentor ever since. The manuscript was improved by the comments and suggestions of Drs. Robin G. Pritchard, Luke L.Y. Chang and Robert F. Martin. The author acknowledges the generosity of Dr. Pete Dunn, Smithsonian Institution, for providing research samples, and is indebted to Dr. Frank C. Hawthorne, University of Manitoba, for making available his laboratory equipment.

\section{REFERENCES}

Grice, J.D., Cooper, M.A. \& Hawthorne, F.C. (1999): Crystal-structure determination of twinned kettnerite. Can. Mineral. 37, 923-927.

\& DunN, P.J. (2000): Crystal-structure determination of pinalite. Am. Mineral. 85, 806- 809 .

\& GaulT, R.A. (1998): Thomasclarkite-(Y), a new sodium - rare-earth element bicarbonate mineral species from Mont Saint-Hilaire, Quebec. Can. Mineral. 36, 1293-1300.

Van Velthuizen, J. \& Gault, R.A. (1994): Petersenite-(Ce), a new mineral from Mont Saint-Hilaire, and its structural relationship to other REE carbonates. Can. Mineral. 32, 405-414.

HerbSt-IRMER, R. \& SHELdRICK, G.M. (1998): Refinement of twinned structures with SHELXL97. Acta Crystallogr. B54, 443-449. (a)
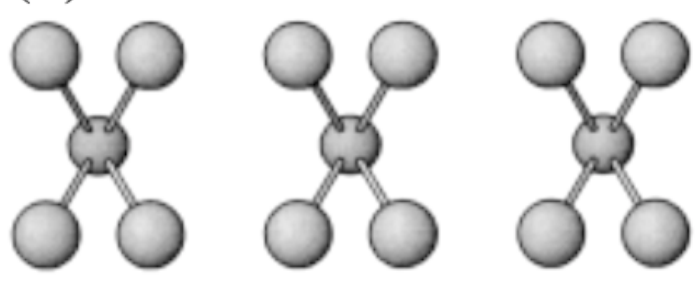

(b)
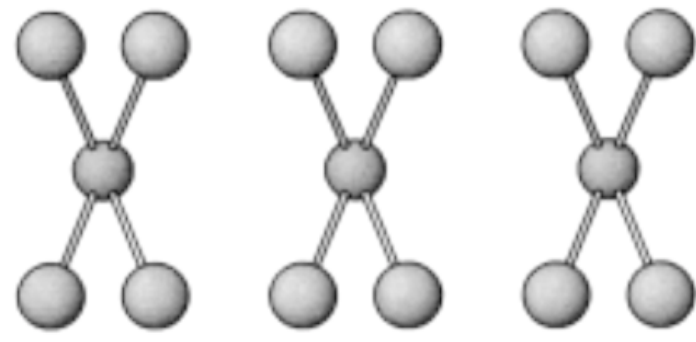

FIG. 6. The $\mathrm{Ca}-\mathrm{O}$ layer in beyerite projected on (a) (100) and (b) (001). The $\mathrm{Ca}^{2+}$ atom is the smaller circle, and $\mathrm{O}^{2-}$, the larger.

HöNLE, W. \& von Schnering, H.G. (1988): Can X-ray crystal-structure analysis decide between twinning by pseudomerohedry and statistical distribution in $\mathrm{YBa}_{2} \mathrm{Cu}_{3} \mathrm{O}_{7}$ ? $\mathrm{Z}$. Kristallogr. 184, 301-305.

LAgERgantZ, A. \& SilléN, L.A. (1948): On the crystal structure of $\mathrm{Bi}_{2} \mathrm{O}_{2}\left(\mathrm{CO}_{3}\right)_{2}$ (bismutite) and $\mathrm{CaBi}_{2} \mathrm{O}_{2}\left(\mathrm{CO}_{3}\right)_{2}$ (beyerite). Arkiv Kemi, Mineral. Geol. 25A, 1-21.

Le Page, Y. (1987): Computer derivation of the symmetry elements implied in a structure description. J. Appl. Crystallogr. 20, 264-269.

Ni, YunXiang, Hughes, J.M. \& Mariano, A.N. (1993): The atomic arrangement of bastnäsite- $(\mathrm{Ce}), \mathrm{Ce}\left(\mathrm{CO}_{3}\right) \mathrm{F}$, and structural elements of synchysite-(Ce), röntgenite-(Ce), and parisite-(Ce). Am. Mineral. 78, 415-418.

North, A.C.T., Phillips, D.C. \& Mathews, F.S. (1968): A semi-empirical method of absorption correction. Acta Crystallogr. A24, 351-359.

SILLÉN, L.G. (1942): Uber eine Familie von Oxyhalogeniden. Naturwiss. 30, 318-324.

Received December 6, 1999, revised manuscript accepted May $20,2000$. 